\title{
The clinical value of phase-contrast CMR mitral inflow diastolic parameters: comparison with echocardiography
}

\author{
Emilie Bollache ${ }^{1 *}$, Alban Redheuil ${ }^{2}$, Carine Defrance ${ }^{3}$, Ludivine Perdrix ${ }^{3}$, Benoît Diebold ${ }^{3}$, Elie Mousseaux ${ }^{2}$, \\ Nadjia Kachenoura
}

From 2011 SCMR/Euro CMR Joint Scientific Sessions

Nice, France. 3-6 February 2011

\section{Purpose}

To evaluate the ability of phase-contrast cardiovascular magnetic resonance (PC-CMR) blood flow diastolic parameters to characterize left ventricular (LV) diastolic dysfunction.

\section{Introduction}

Early detection of LV diastolic dysfunction is crucial for the management of patients with heart disease. PC-CMR is increasingly used for this evaluation. However, its usefulness in clinical routine is not established yet because of technical issues such as the lack of automated post-processing tools. We hypothesized that the analysis of velocity and flow-rate curves extracted from an accurate segmentation of the transmitral flow would provide sensitive diastolic parameters.

\section{Methods}

We studied 35 healthy controls ( 21 women; age: $38 \pm 16$ years) and 12 consecutive patients ( 8 women; age: $81 \pm 5$ years) with a severe aortic stenosis (valve area/body surface $=0.47 \pm 0.17 \mathrm{~cm}^{2} / \mathrm{m}^{2}$, ejection fraction $=66 \pm 16 \%$, enddiastolic volume $=94 \pm 18 \mathrm{ml}$, end -systolic volume $=33 \pm 19$ $\mathrm{ml}$ ). All subjects had an echocardiography (GE Vivid 7) and a transmitral flow PC-CMR acquisition (GE 1.5 T) on the same day. For PC-CMR images analysis, we used our custom software for semi-automated segmentation of transmitral flow and automated extraction of diastolic parameters from velocity and flow rate curves. Flow rate curves provided: 1$)$ peak filling rate $\left(\mathrm{Ef}_{\mathrm{MR}}, \mathrm{ml} / \mathrm{s}\right)$ and

${ }^{11}$ INSERM U678, Paris, France

Full list of author information is available at the end of the article peak atrial filling rate $\left(\mathrm{Af}_{\mathrm{MR}}, \mathrm{ml} / \mathrm{s}\right)$ combined into $\mathrm{Ef}_{\mathrm{MR}} /$ $\left.\mathrm{Af}_{M R}, 2\right)$ peak filling rate to filling volume ratio $\left(\mathrm{Ef}_{\mathrm{MR}} /\right.$ $\mathrm{FVf}_{\mathrm{MR}}, \mathrm{s}^{-1}$ ), and 3) the deceleration time (DTf $\mathrm{DR}_{\mathrm{MR}}$ ), while maximal velocity curves provided the early and late peak velocities $E_{M R}$ and $A_{M R}$, combined into $E_{M R} / A_{M R}$. $D_{T} T_{U S}$ and $E_{U S} / A_{U S}$ as well as the flow to tissue velocity ratio $E_{U S} / E_{\text {US }}^{\prime}$ were estimated from Doppler echocardiography.

\section{Results}

A stronger correlation and a slope closer to 1 was found for the comparison between the echocardiographic $\mathrm{E}_{\mathrm{US}} / \mathrm{A}_{\mathrm{US}}$ and the flow rate-related $\mathrm{Ef}_{\mathrm{MR}} / \mathrm{Af}_{\mathrm{MR}}(\mathrm{r}=0.80$, $\left.\mathrm{Ef}_{\mathrm{MR}} / \mathrm{Af}_{\mathrm{MR}}=0.89 \cdot \mathrm{E}_{\mathrm{US}} / \mathrm{A}_{\mathrm{US}}+0.09\right)$ than the velocity-related $\mathrm{E}_{M R} / \mathrm{A}_{M R}\left(\mathrm{r}=0.72, \mathrm{E}_{\mathrm{MR}} / \mathrm{A}_{\mathrm{MR}}=0.55 \cdot \mathrm{E}_{\mathrm{US}} / \mathrm{A}_{\mathrm{US}}+0.49\right)$. Results of receiver operating characteristic (ROC) analysis summarized in table 1 indicated the good sensitivity and specificity of the PC-CMR parameters to separate controls from patients.

Table 1 Summary of echocardiographic and CMR diastolic parameters for controls and patients and their ability to characterize pathological subjects. AUC=area under the ROC curve

\begin{tabular}{llllll}
\hline & Controls & Patients & Sensitivity & Specificity & AUC \\
\hline EUS/AUS & $1.39 \pm 0.60$ & $0.82 \pm 0.33$ & 94 & 67 & 0.86 \\
EUS/E'US & $5.34 \pm 1.83$ & $14.3 \pm 8.10$ & 83 & 100 & 0.96 \\
DTUS(ms) & $180 \pm 56$ & $271 \pm 58$ & 77 & 92 & 0.86 \\
EMR/AMR & $1.34 \pm 56$ & $271 \pm 58$ & 77 & 92 & 0.86 \\
EfMR/AfMR & $1.44 \pm 0.58$ & $0.49 \pm 0.20$ & 91 & 92 & 0.95 \\
DTfMR(ms) & $187 \pm 36$ & $258 \pm 45$ & 86 & 83 & 0.88 \\
EfMR/FVFMR (s-1) & $4.26 \pm 0.94$ & $2.37 \pm 0.55$ & 91 & 100 & 0.97 \\
\hline
\end{tabular}




\section{Conclusions}

Our automated method provided diastolic parameters in good agreement with Doppler echocardiography especially for our new $\mathrm{Ef}_{\mathrm{MR}} / \mathrm{Af}_{\mathrm{MR}}$ ratio estimated from flow rate analysis. In addition, our preliminary findings indicated their high sensitivity and specificity to determine patients from controls. The addition of tissue velocities analysis, which is under investigation, to our tool would increase this efficiency.

\section{Author details}

${ }^{11}$ INSERM U678, Paris, France. ${ }^{22}$ Radiology department, European Hospital Georges Pompidou, Paris, France. ${ }^{33}$ Echocardiography department, European Hospital Georges Pompidou, Paris, France.

Published: 2 February 2011

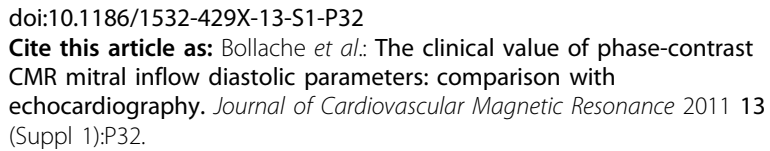

Submit your next manuscript to BioMed Central and take full advantage of:

- Convenient online submission

- Thorough peer review

- No space constraints or color figure charges

- Immediate publication on acceptance

- Inclusion in PubMed, CAS, Scopus and Google Scholar

- Research which is freely available for redistribution 